\title{
Biostratigraphy and assigning the paleosalinity by using Echinocorys and Planktonic foraminifera at Upper Maastrichtian, in Jorband section, Central Alborz, Iran
}

\author{
Masood Asgharian rostami ${ }^{1}$, Behnaz Balmaki ${ }^{2}$, Meysam Shafiee ardestani ${ }^{1}$, Esmail \\ Kohansal (DATA) ${ }^{1}$ \\ 1- Department of Geology, Faculty of Science, University of Tehran, Tehran,Iran \\ 2-Department of Geology, Faculty of Science, University of Hamedan, Hamedan, Iran \\ E-mail: m_shafieeardestani@yahoo.com
}

\begin{abstract}
Jorband section is located in the north slope of central Alborz, and $28 \mathrm{Km}$ in south of Noor. It has been sampled and index fossilic groups of planktonic foraminifera and echinoids were studied in order to assign the paleosalinity and biozonation in central Alborz. The planktonic foraminiferal biozones identified within the Upper maastrichtian sequence of the Jorband section are three zones of Contustruncana contusa, Planoglobulina brazoensis, and Racemiguembelina fructicosa. The salinity changes were also searched in this section. In three layers in Jorband section examination echinocorys genus and is drawn as a diagram which in middle of the section, the salinity mounts is fewer than the beginning and top of the section.
\end{abstract}

Key word: Paleosalinity, Biozonation, Echinocorys, Central Alborz

\section{Introduction}

Planktonic foraminifera are one of the most prominent index microfossils to biozonation, because of abundance, Great variety, wide spreading and rapidly evolution in upper cretaceous. Mean time, Planktonic foraminifera are the most important fossilic groups in order to searching and interpreting the paleoenvironments. Echinoids also are the best groups to annotate the paleoenvironment especially salinity (Wisshak and Neumann, 2006).

In this research the biostratigraphy and salinity was searched by planktonic foraminifera and echinoids. In order to
Jorband section was selected do the searches in central Alborz. In Jorband section the echinocorys genuses which are vulnerable in salinity changes, were studied in order to determining the salinity mount. At all echinocorys have a vice versa connection with salinity, and their amount will increase by decreasing the salinity (Stephens \& Virkar 1966).

In this section the salinity amount will increase then it will decrease, and finally it will increase again, that this salinity vacillation is confirmed with due attention to the physiologic changes of 
echinocorys body in regulating of osmotic pressure.

\section{Location, lithology and Procedures}

Jorband section is located in the north slope of Central Alborz, and $28 \mathrm{Km}$ in south of Noor, with geographic characteristics of $36^{\circ} 20^{\prime} 32^{\prime \prime}$ and $52^{\circ}$ 20' 32" (Fig 1). The section of the study belong to Upper Maastrichtian and has a thinkness has about $15 \mathrm{~m}$, includes marl. A total of 35 samples were collected from the section, which were soaked in water with diluted hydrogen peroxide, washed through $63 \mu \mathrm{m}, 150 \mu \mathrm{m}$ and $250 \mu \mathrm{m}$ sieves, and dried until clean foraminiferal residues were recovered. About 200-300 individuals were picked up for each sample in two size fractions $(63-150 \mu \mathrm{m}$ and $>150 \mu \mathrm{m})$ and mounted on dark cardboard slides for identification.At last to separating the sediments from microfossils, the sample were in ultrasonic machine for 15 minute and they were washed again and finally, the remain sample were studied binocular microscope. The metallurgy research center has prepared SEM photographs from the chosen samples. These two size fractions were analyzed in order to obtain statistically significant representatives of the small and large groups

In order to recognizing the planktonic foraminifera it is used from valid resources such as (Caron, 1985, Robaszynski et al, 1995- 1984, Nederbraght, 1991).

\section{Discussion}

\section{A: Biostratigrapy}

An exactly zonation for upper cretaceous is presented by Li et al (

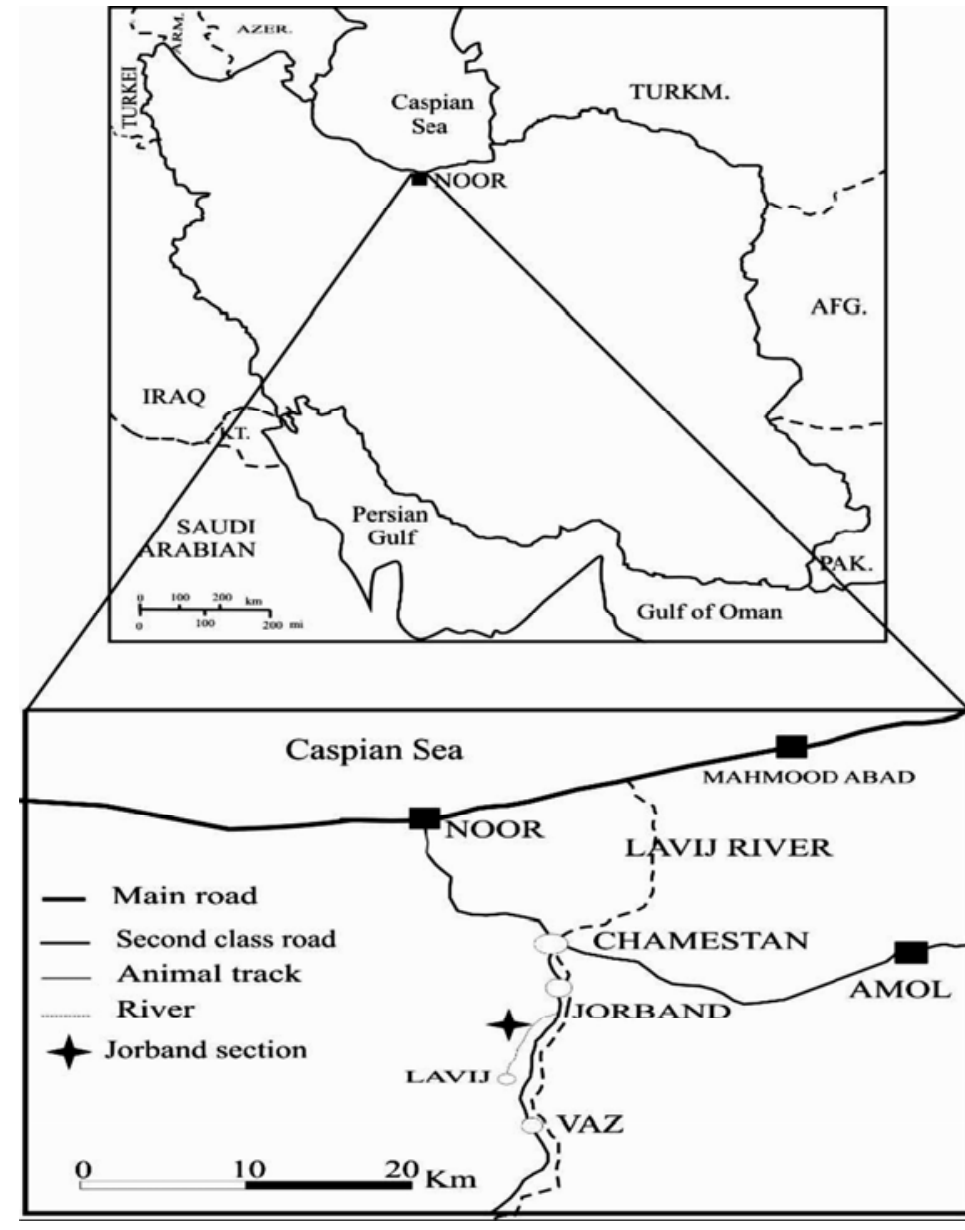

Fig 1.Location map of the studied area in the Iran.

$\mathrm{Li}$ and Keller 1998a) and $\mathrm{Li}$ and others (Li at al, 1999) and it is used as a base for many of later studied like the studies in Tunisia ( $\mathrm{Li}$ and Keller 1998b, Abromovich et al 2002), and Bulgaria (Adatte et al, 2002) in this zonation upper maastrechtian is divided in to eight biozones that in Jorband section 3 zones of Contusotruncana contusa, planoglobulina brazoensis and Racemiguemblina fructicosa, were recognized out of these biozones (Fig2).

\section{Contusotruncana contusa Interval zone of Li et al, 1998a:}

The Rosita contusa or CF6 Zone is defined by the FA of the nominate taxon at the base and the Lo of Globotruncana linneiana at the top. 
This zone is equal with CF6 zone of li and Keller (Li et al, 1998) and has $2 \mathrm{~m}$ Thickness in Jorband section and it is age is equal with Eary Maastrchtian,

\section{Planoglobulina brazoensis partial range zone}

The Planoglobulina brazoensis or Cf5 Zone is defined by the Lo of the nominate taxon Globotruncana linneiana at the base and the Fo of Racemiguembelina fructicosa at the top. This zone is equal with Pseudotextularia intermedia zone of (Li and Keller 1998a) and (Li et al, 1999) these scientist belive that, despite the appearing of P.intermedia in CF6 zone for the first time, but their development morphotype is appearing in CF5 zone ( $\mathrm{Li}$ and Keller, 1998a) although the first appearing of $P$. intermedia in Jorband section is in the zone of CF10.this zone has $6 \mathrm{~m}$ thickness.

\section{Racemiguembelina fructicosa Interval zone li et al $1998^{a}$}

The Racemiguembelina fructicosa or CF4 Zone is defined by the Fos of $R$. fructicosa at the base and $P$. hariaensis at the top. The boundary of this zone is not obviously clear. This zone is equal with CF4 zone of $\mathrm{Li}$ and Keller ( $\mathrm{Li} \&$ Keller, 1998a) and li coworkers (Li et al, 1999) and has $7 \mathrm{~m}$ thickness and has an equal age with the beginning of Upper Maastrichtian.

\section{Salinity appointing}

Appointing the salinity was done by echinocorys genus in this section. Echinocorys have a shell between medium and large, and a test with a high slope and a smooth basically surface, and have an angled ambitus with short and clear pins, in order to protect the adaptical surface. Also they have spoon pins which are connected to front mount surface with some lumpus, and they have to move and push the echinocorys forwarded (Clarkson 2006).

They have an ambulacra which are not petaloids and are in large size and were seen a lot in Upper Maastrichtian sediments of late cretaceous in north of Alborz (Balmaki, 2007)

The echinoids not only live in less salinity areas but also like in high salinity places. The affection of salinity changes is reveal in any of their surface.

The salinity changes would affection abundance, death, population dispersion, moves, some change in nourish and metabolism behaviors, fastness of growth and reproduction (Wisshak and Neumann, 2006)

The echinoids are a perfect group that used as a tool to interpretation the paleoenvironment. Some of echinoids do not have an obvious organism to regulate the osmotic pressure most of the spices have lived their habitat because of salinity changes and migrated to other places or die because of these changes. Echinocoryses are one of these groups. The salinity changes percent has indicated between -20 till -30 , it means that the maximum of salinity changes in echinocorys environment is 10 (Ellington , 1982) at all the echinocoryses abide the salinity 34 degree. The aminoacides number would increase in echinoids cell's in environmental situation changes that this behavior happens in echinocorys because of increasing the salinity of environment (Stephen \& Virkar 1966).

The main role of enzymes cells is to accelebrate the regulating reactions in amino acids.

But in the situation which the environment salinity is increasing, they have a vice versa effect on enzymes, and would forbid the enzymes to work appropriately inside the cells (Ellington, 1982). In order to do the process of study in area, the salinity changes in the end of Maastrichtian presented as a chart with due attention to the counting and assessment of echinocorys in 3 
layers, that the most number of this genus were there.

In the beginning of section there is a less percent of this genus (30 percent). In the middle of section it is abundant $\mathrm{s} 80$ percent and it will diminish again in the bottom and gets to 55 percent (Fig2).

The ion body surface balance of echinocorys would be done during 12 till 24 hours because of salinity changes. The fluid of cell would increase the density amount of amino acids and $\mathrm{K}+$ but it would decrease the concentration amount of $\mathrm{Cl}^{-}$and $\mathrm{Na}+$ increase it can effects on decreasing the echinocorys (Diehi, 1983).

The regulation of osmotic pressure inside the echinocorys body possibly arises from the salinity amount changing and ion changing amount, of around environment that this can effects on test potential and can be a reason to activate that enzymes and shape changing of structure and surface. The amount of $\mathrm{K}+$ is appointed about 11.5 and 13.4 in terms of litter (Beth \& Berger, 1931). In this section the changes of echinocorys test is obviously clear.

\section{Conclusion}

In end of maastrichtian in Jorband section, three zones of Contustruncana contusa, Planoglobulina brazoensis, Racemiguembelina fructicosa, were indicated based on the planktonic foraminifera. The salinity changes were also determined in three layers in this section based on Echinocorys genus, the consequence is drawn as

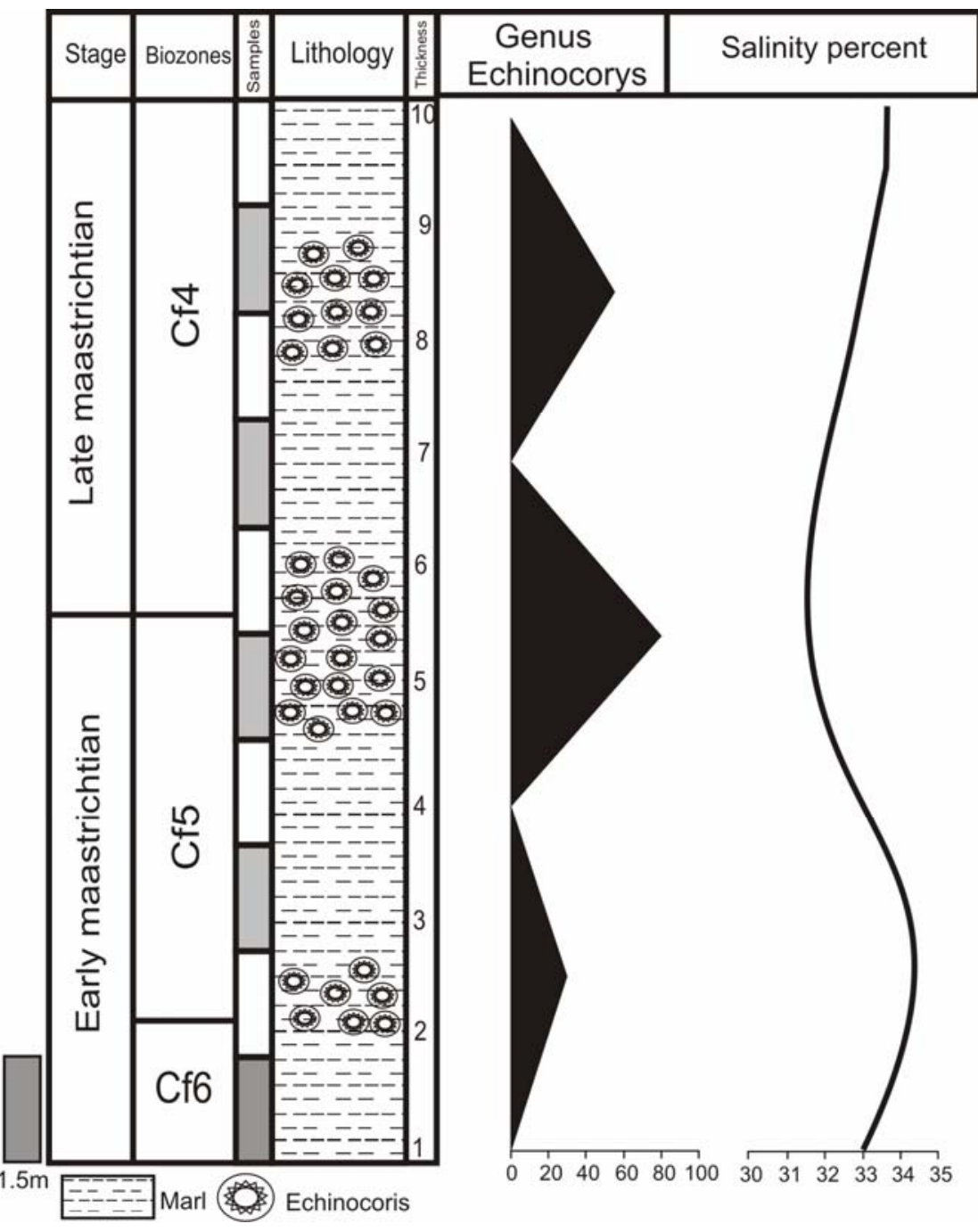

Fig 2. Display of biostratigraphy and salinity change by planktonic foraminifera and Echinocorys

a diagram which in middle of the section, the salinity rate is fewer than the beginning and bottom of the section.

\section{Reference}

Abramovich, S., and Keller, G., (2002). High stress late Maastrichtian paleoenvironment: inference from planktonic foraminifera in Tunisia; Palaeogeography, Palaeoclimatology, Palaeoecology 178: 145-164.

Adatte, T., Keller, G., and Stinnesbeck, W., (2002). Late Cretaceous to early Paleocene climate and sea-level fluctuations: the Tunisian record; 
Palaeogeography, Palaeoclimatology, Palaeoecology 178: 165-196.

Balmaki, b, 2007, a symbiotic relationship of echinocorys faunas from the northern alborz mountains, $51^{\text {st }}$ palaeontological association annual meeting, December 16-19, Uppsala, Sweden.

Bethe A and Berger E. (1931) variationen im mineralbestand verschiedener blutaten. pflugers arch, ges. physiol. 227, 571584.

Caron, M., 1985- Cretaceous planktic foraminifera. In Bolli, H. M., Saunders, J. B., and Perch-Nielsen, K. (Eds.), Plankton Stratigraphy: Cambridge (Cambridge Univ. Press), 17-86.

Diehl W. J. (1983) Pattern and mechanisms of isosmitic intracellular regulation in Luidia clathrata (say) (Echinodermata: asteroidean) exposed to hypo- and hyperosmotic stress. PH.D. Dissertation. University of south Florida, Tampa.

Ellington W.R.(1982) intermediary metabolism. In echinoderm nutrition (edited by Jangoux M. and Lawrence J. M.), pp. 395-415. a.a. balkema, Rotterdam.

Li, L. and Keller, G. (1998a). Maastrichtian climate, productivity and faunal turnovers in planktic foraminifera in South Atlantic DSDP Sites 525 and 21. Marine Micropaleontology 33, 55-86.

Li, L. and Keller, G. (1998b). Maastrichtian diversification of planktic foraminifera at El Kef and Elles, Tunisia. Eclogae Geologicae Helvetiae 91, 75-102.
Li, L., Keller, G. and Stinnesbeck, W. (1999). The Late Campanian and Maastrichtian in northwestern Tunisia: Paleoenvironmental inferences from lithology, macrofauna and benthic foraminifera. Cretaceous Research 20, 231-252.

Nederbragt, A.J.,1991- Late Cretaceous biostratigraphy and development of Heterohelicidae planktic foraminifera. Micropaleontology, 37:329-372.

Robaszynski, F., Caron, M., Gonzales Donoso, J.M., and Wonders, A.A.H., (1984). Atlas of Late Cretaceous Globotruncanids; Revue de Micropaléontologie 26, 145-305.

Stephens G.C. and Virkar R.A. (1966) uptake of organic material by aquatic invertebrates. IV. The influence of salinity on the uptake of amino acids by the brittle star, Ophiactis arenosa. Boil. Bull. 131, 172-185.

Wisshak, m. and Neumann, C. 2006. A symbiotic association of a boring polychaete and echinoid from the late cretaceous of Germany. Acta palaeontologica polonica 51(3): 589597. 

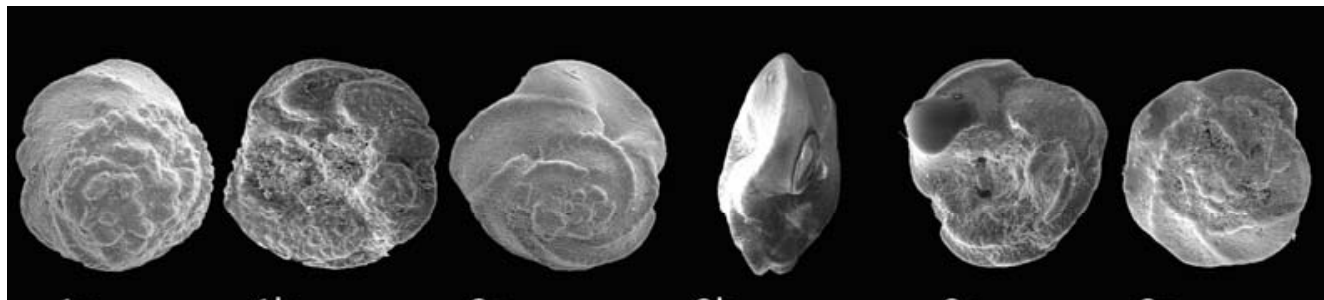

$1 a$

$2 a$

$2 b$

$2 c$

$3 a$

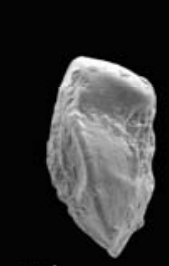

$3 b$

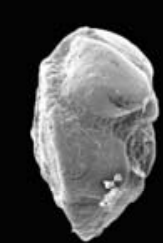

$5 b$

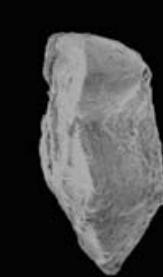

7b

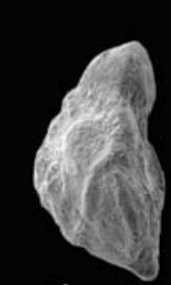

$9 b$

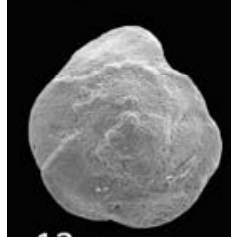

$12 a$



$3 c$

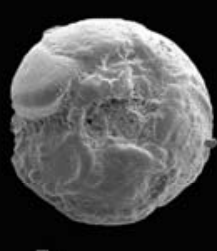

$5 c$

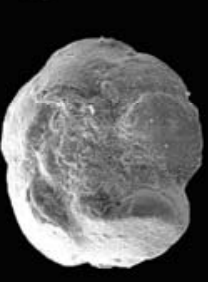

$7 c$

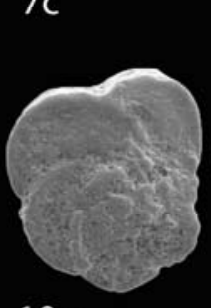

$10 a$

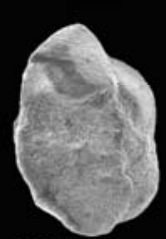

$12 b$



$4 a$

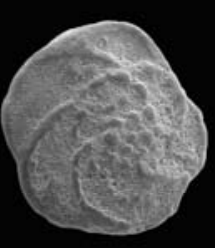

$6 a$



$8 a$

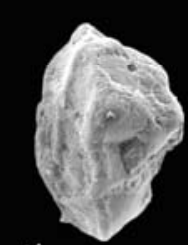

$4 \mathrm{~b}$

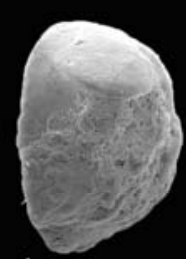

$6 b$



$4 c$

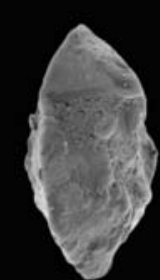

$8 b$

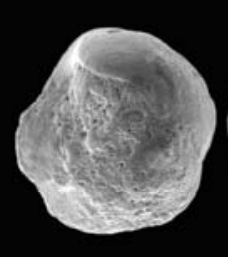

$6 c$
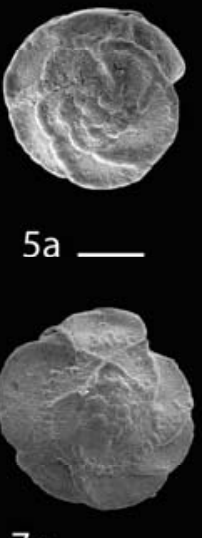

a

Plate1: 1- Contusotruncana patelliformis (Gandolfi) 1955; sample no. 3; Racemiguembelina fructicosa Zone; scale bar represent 100 $\mu \mathrm{m}$. 1a: spiral view. 1b: peripheral view. 1c: umbilical view.2- Contusotruncana fornicata (Plummer) 1931; sample no. 3; Racemiguembelina fructicosa Zone; scale bar represent $100 \mu \mathrm{m}$. 2a: spiral view. 2b: peripheral view. 2c: umbilical view.3Globotruncanita stuartiformis (Dalbiez) 1955: sample no. 59; Pseudoguembelina palpebra Zone. 3a: spiral view. 3b: lateral view. 3c: umbilical view.4- Globotruncanita stuartiformis (Dalbiez) 1955: sample no. 17; Pseudoguembelina hariaensis Zone. 4a: spiral view. 4b: lateral view. 4c: umbilical view.5- Globotruncanita stuarti (de Lapparent) 1918: sample no. 1; Racemiguembelina fructicosa Zone. 5a: spiral view. 5b: lateral view. 5c: umbilical view.6- Globotruncanita angulata (Tiler)1951: sample no. 23; Pseudoguembelina hariaensisZone. 6a: spiral view. 6b: lateral view. 6c: umbilical view.7- Globotruncanita insignis (Gandolfi) 1955: sample no. 33; Pseudoguembelina hariaensisZone. 7a: spiral view. 7b: lateral view. 7c: umbilical view.8- Globotruncanita stuartiformis (Dalbiez) 1955: sample no. 17; Pseudoguembelina hariaensisZone. 8a: spiral view. 8b: lateral view. 8c: umbilical view.9- Contusotruncana sp. (Todd) 1970: sample no. 56; Pseudoguembelina palpebra Zone. 9a: spiral view. 9b: lateral view.10Globotruncana linneiana (d'Orbigny) 1839: sample no. 1; Racemiguembelina fructicosa Zone. 10a: spiral view. 10b: umbilical view.11- Globotruncana mariei Banner \& Blow 1960; sample no. 59; Pseudoguembelina palpebra zone; 11a: spiral view. 11b: peripheral view. 11c: umbilical view.12- Globotruncana rosetta (Carsey) 1926; sample no. 11; Pseudoguembelina hariaensis Zone. 12a: spiral view. 12b: peripheral view. 12c: umbilical view.13- Globotruncana arca (Cushman) 1926: sample no. 66; Pseudoguembelina palpebra Zone.13a: spiral view.13b: spiral view 13c: umbilical view.Scale:100 $\mu \mathrm{m}$. 


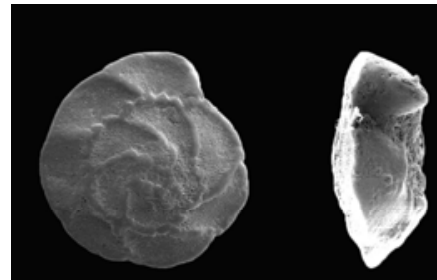

$1 \mathrm{a}$

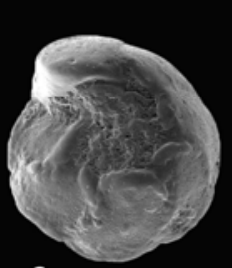

2c

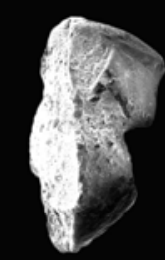

$4 b$

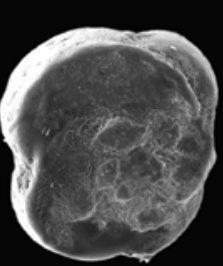

$6 a$

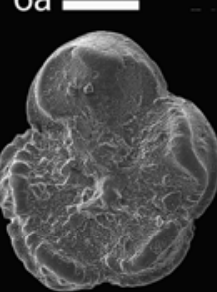

7c

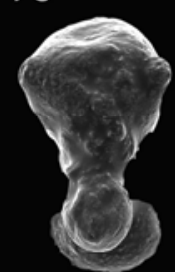

$9 \mathrm{~b}$ 1b

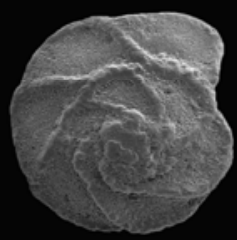

$3 a$

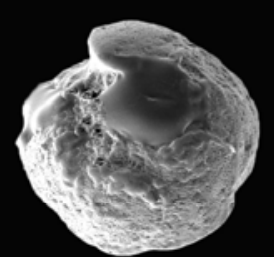

$4 \mathrm{C}$

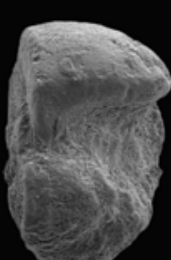

$6 b$

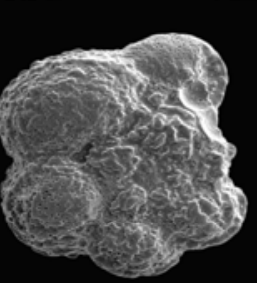

$8 a$
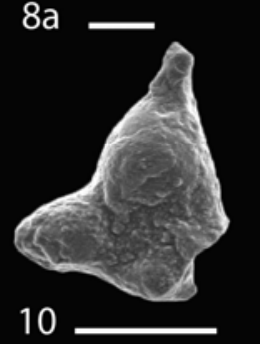

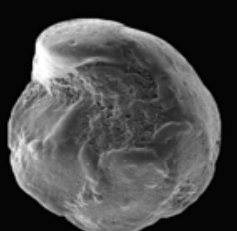

$1 c$

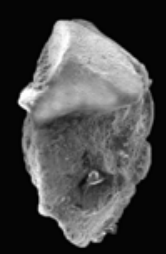

3b

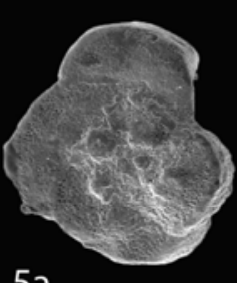

$5 a$

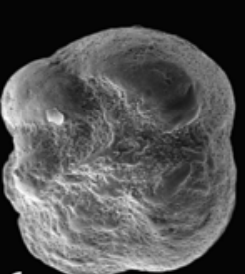

$6 c$

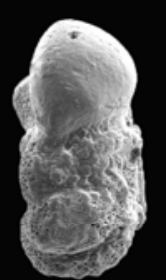

$8 b$





$2 a$

$2 b$

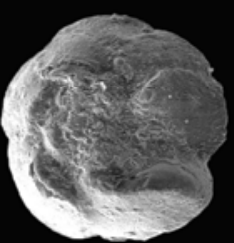

$3 c$

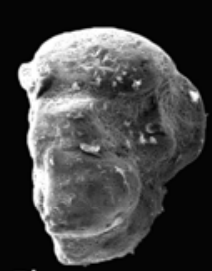

$5 b$



$4 a$

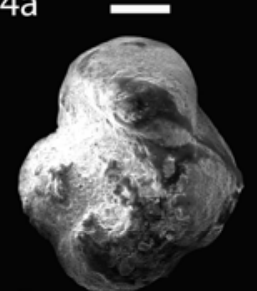

$5 c$



$7 b$


$9 a$



$8 c$

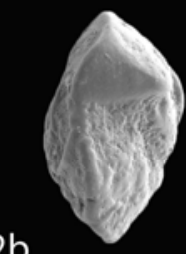

(2)

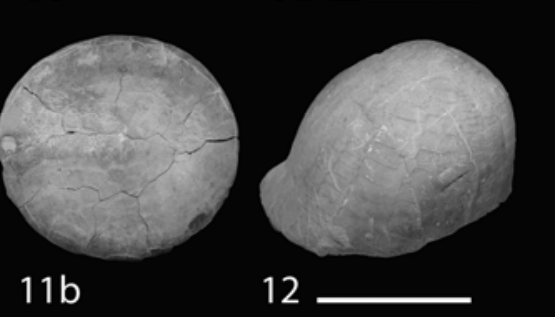

Plate2:1- Globotruncanita stuarti (de Lapparent) 1918: sample no. 17; Pseudoguembelina hariaensisZone. 1a: spiral view. 1b: lateral view. 1c: umbilical view. 2- Globotruncanita stuartiformis (Dalbiez) 1955: sample no. 1; Racemiguembelina fructicosa (Egger) 1899 Zone. 2a: spiral view. 2b: lateral view. 2c: umbilical view.3-3- Globotruncanita stuartiformis (Dalbiez) 1955: sample no. 23;. Pseudoguembelina hariensis. 3a: spiral view. 3b: lateral view. 3c: umbilical view. 4- Gansserina wiedenmayeri (Gandolfi) 1955: sample no. 17; Pseudoguembelina hariaensisZone. 4a: spiral view 4b: lateral view. 4c: umbilical view. 5- Gansserina gansseri (Bolli) 1951: sample no. 33; Pseudoguembelina hariaensisZone. $\quad$ 5a: spiral view 5b: lateral view. 5c: umbilical view. 6- Gansserina wiedenmayeri (Gandolfi) 1955: sample no. 10; Pseudoguembelina hariaensisZone. $\quad$ 6a: spiral view 6b: lateral view. 6c: umbilical view.7- Abathomphalus mayaroensis (Bolli) 1951: sample no. 33: Pseudoguembelina hariaensisZone; scale bar represent $100 \mu$ m. 7a: spiral view. 7b: peripheral view. 7c: umbilical view.8- Trinitella scotti (Brönnimann) 1952; sample no. 67; Pseudoguembelina palpebra Zone; scale bar Represent $100 \mu \mathrm{m}$. 8a: spiral view 8b: peripheral view. 8c: umbilical view.9- Schackoina multispinata (Cushman \& Wickenden) 1930; sample no. 85; Pseudoguembelina palpebra Zone; scale bar represent $50 \mu$ m; peripheral view. Peripheral view.10- Schackoina cenomana (schako) 1897; sample no. 83; Pseudoguembelina palpebra Zone; scale bar Represent 50 $\mu \mathrm{m}$. Spiral view.11, 12-Echinocorys schotata. Scale: $100 \mu \mathrm{m}$ except for samples 11,12 . Scale bar5cm. 